\title{
Kaitianite, $\mathrm{Ti}^{3+}{ }_{2} \mathrm{Ti}^{4+} \mathrm{O}_{5}$, a new titanium oxide mineral from Allende
}

\author{
Chi MA (D)* and John R. BECKETT \\ Division of Geological and Planetary Sciences, California Institute of Technology, Pasadena, California 91125, USA \\ *Corresponding author. E-mail: chima@caltech.edu
}

(Received 15 December 2019; revision accepted 09 September 2020)

\begin{abstract}
Kaitianite, $\mathrm{Ti}^{3+}{ }_{2} \mathrm{Ti}^{4+} \mathrm{O}_{5}$, is a new titanium oxide mineral discovered in the Allende CV3 carbonaceous chondrite. The type grain coexists with tistarite $\left(\mathrm{Ti}_{2} \mathrm{O}_{3}\right)$ and rutile. Corundum, xifengite, mullite, osbornite, and a new Ti,Al, $\mathrm{Zr}$-oxide mineral are also present, although not in contact. The chemical composition of type kaitianite is ( $\mathrm{wt} \%) \mathrm{Ti}_{2} \mathrm{O}_{3} 56.55$, $\mathrm{TiO}_{2}$ 39.29, $\mathrm{Al}_{2} \mathrm{O}_{3}$ 1.18, $\mathrm{MgO} 1.39, \mathrm{FeO} 0.59, \mathrm{~V}_{2} \mathrm{O}_{3} 0.08$ (sum 99.07), yielding an empirical formula of $\left(\mathrm{Ti}^{3+}{ }_{1.75} \mathrm{Al}_{0.05} \mathrm{Ti}^{4+}{ }_{0.10} \mathrm{Mg}_{0.08} \mathrm{Fe}_{0.02}\right)\left(\mathrm{Ti}^{4+}{ }_{1.00}\right) \mathrm{O}_{5}$, with $\mathrm{Ti}^{3+}$ and $\mathrm{Ti}^{4+}$ partitioned, assuming a stoichiometry of three cations and five oxygen anions pfu. The end-member formula is $\mathrm{Ti}^{3+}{ }_{2} \mathrm{Ti}^{4+} \mathrm{O}_{5}$. Kaitianite is the natural form of $\gamma-\mathrm{Ti}_{3} \mathrm{O}_{5}$ with space group $C 2 / c$ and cell parameters $a=10.115 \AA, b=5.074 \AA, c=7.182 \AA, \beta=112^{\circ}, V=341.77 \AA^{3}$, and $Z=4$. Both the type kaitianite and associated rutile likely formed as oxidation products of tistarite at temperatures below $1200 \mathrm{~K}$, but this oxidation event could have been in a very reducing environment, even more reducing than a gas of solar composition. Based on experimental data on the solubility of $\mathrm{Ti}^{3+}$ in equilibrium with corundum from the literature, the absence of tistarite in or on $\mathrm{Ti}^{3+}$-rich corundum $\left(0.27-1.45 \mathrm{~mol} \% \mathrm{Ti}_{2} \mathrm{O}_{3}\right)$ suggests that these grains formed at higher temperatures than the kaitianite (>1579-1696 K, depending on the Ti concentration). The absence of rutile or kaitianite in or on corundum suggests that any exposure to the oxidizing environment producing kaitianite in tistarite was too short to cause the precipitation of Ti-oxides in or on associated corundum.
\end{abstract}

\section{INTRODUCTION}

Fifty years after Allende fell, this CV3 chondrite continues to be a source of new discoveries. Allende has, for example, yielded 19 new minerals since 2007 (Table 1), including numerous examples of refractory and ultra-refractory phases and their alteration products. Each of these new minerals adds a piece to the puzzle of understanding nebular and parent body processes in the early solar system. Here, we describe an occurrence of kaitianite, $\mathrm{Ti}^{3+}{ }_{2} \mathrm{Ti}^{4+} \mathrm{O}_{5}$, the latest new mineral to be discovered in Allende.

During an ongoing nanomineralogy investigation of the Allende $\mathrm{CV} 3$ carbonaceous chondrite, the new mineral kaitianite, $\mathrm{Ti}^{3+}{ }_{2} \mathrm{Ti}^{4+} \mathrm{O}_{5}$ with a $C 2 / c \quad \mathrm{~V}_{3} \mathrm{O}_{5}$-type structure, was identified in section USNM 3510-5 (Fig. 1) and accorded new mineral status in 2017 by the International Mineralogical Association's Commission on New Minerals, Nomenclature, and Classification
(IMA 2017-078a; Ma 2018). Synthetic $\mathrm{Ti}_{3} \mathrm{O}_{5}$ with the $C 2 / c \quad \mathrm{~V}_{3} \mathrm{O}_{5}$-type structure is referred to as $\gamma-\mathrm{Ti}_{3} \mathrm{O}_{5}$ (Hong and Asbrink 1982; Tanaka et al. 2015).

Ma (2019) gave a preliminary description of the first occurrence of kaitianite, which is expanded in this study. In a brief report, Brearley (1993) reported the occurrence of a fine-grained $\mathrm{Ti}_{3} \mathrm{O}_{5}$ phase within a chondrite matrix clast in the Nilpena polymict ureilite. This phase has a $C 2 / m \mathrm{Ti}_{3} \mathrm{O}_{5}$-type structure (i.e., it is not kaitianite). $\mathrm{Ma}$ et al. (2012) described panguite in an Allende ultrarefractory inclusion with a formula of $\left(\mathrm{Ti}^{4+}, \mathrm{Al}, \mathrm{Sc}, \mathrm{Mg}, \mathrm{Zr}\right.$, Ca) ${ }_{1.8} \mathrm{O}_{3}$. This phase has a $P b c a$ bixbyite $\mathrm{Mn}_{2} \mathrm{O}_{3}$-related structure that can be derived from $\left(\mathrm{Ti}^{4+}, \mathrm{Al}, \mathrm{Sc}, \mathrm{Mg}, \mathrm{Zr}\right.$, $\mathrm{Ca})_{3} \mathrm{O}_{5}$. Zhang et al. (2015) observed Sc-rich $\mathrm{Ti}_{3} \mathrm{O}_{5}$ in an ultra-refractory inclusion from the $\mathrm{CH} 3$ chondrite $\mathrm{SaU}$ 290. This mineral, which remains unnamed, is distinct from kaitianite because it has a $\mathrm{Cmcm}$ pseudobrookitetype structure (in the materials science literature, it is sometimes referred to as anosovite). 
Table 1. Nineteen new minerals discovered in the Allende CV3 chondrite since 2007.

\begin{tabular}{|c|c|c|c|}
\hline IMA no. & Mineral name & Formula & Reference \\
\hline IMA 2007-027 & Allendeite & $\mathrm{Sc}_{4} \mathrm{Zr}_{3} \mathrm{O}_{12}$ & Ma et al. (2014b) \\
\hline IMA 2007-029 & Hexamolybdenum & $(\mathrm{Mo}, \mathrm{Ru}, \mathrm{Fe})$ & Ma et al. (2014b) \\
\hline IMA 2007-033 & Monipite & MoNiP & Ma et al. (2014a) \\
\hline IMA 2008-016 & Tistarite & $\mathrm{Ti}_{2} \mathrm{O}_{3}$ & Ma and Rossman (2009a) \\
\hline IMA 2008-030 & Davisite & $\mathrm{CaScAlSiO}_{6}$ & Ma and Rossman (2009b) \\
\hline IMA 2008-042 & Grossmanite & $\mathrm{CaTi}^{3+} \mathrm{AlSiO}_{6}$ & Ma and Rossman (2009c) \\
\hline IMA 2009-027 & Hibonite-(Fe) & $(\mathrm{Fe}, \mathrm{Mg}) \mathrm{Al}_{12} \mathrm{O}_{19}$ & $\mathrm{Ma}(2010)$ \\
\hline IMA 2010-057 & Panguite & $\left(\mathrm{Ti}^{4+}, \mathrm{Al}, \mathrm{Sc}, \mathrm{Mg}, \mathrm{Zr}, \mathrm{Ca}\right)_{1.8} \mathrm{O}_{3}$ & Ma et al. (2012) \\
\hline IMA 2011-092 & Kangite & $\left(\mathrm{Sc}, \mathrm{Ti}^{4+}, \mathrm{Al}, \mathrm{Zr}, \mathrm{Mg}, \mathrm{Ca}, \square\right)_{2} \mathrm{O}_{3}$ & Ma et al. (2013) \\
\hline IMA 2012-079 & Majindeite & $\mathrm{Mg}_{2} \mathrm{Mo}_{3} \mathrm{O}_{8}$ & Ma and Beckett (2016b) \\
\hline IMA 2013-018 & Nuwaite & $\mathrm{Ni}_{6} \mathrm{GeS}_{2}$ & Ma and Beckett (2018) \\
\hline IMA 2013-029 & Hutcheonite & $\mathrm{Ca}_{3} \mathrm{Ti}^{4+}{ }_{2}\left(\mathrm{SiAl}_{2}\right) \mathrm{O}_{12}$ & Ma and Krot (2014) \\
\hline IMA 2013-053 & Paqueite & $\mathrm{Ca}_{3} \mathrm{TiSi}_{2}\left(\mathrm{Al}_{2} \mathrm{Ti}\right) \mathrm{O}_{14}$ & Ma and Beckett (2016a) \\
\hline IMA 2013-054 & Burnettite & $\mathrm{CaVAlSiO}_{6}$ & Ma and Beckett (2016a) \\
\hline IMA 2014-028 & Adrianite & $\mathrm{Ca}_{12}\left(\mathrm{Mg}_{5} \mathrm{Si}_{9}\right) \mathrm{O}_{32} \mathrm{Cl}_{6}$ & Ma and Krot (2018) \\
\hline IMA 2015-001 & Beckettite & $\mathrm{Ca}_{2} \mathrm{~V}_{6} \mathrm{Al}_{6} \mathrm{O}_{20}$ & Ma et al. (2016) \\
\hline IMA 2016-028 & Butianite & $\mathrm{Ni}_{6} \mathrm{SnS}_{2}$ & Ma and Beckett (2018) \\
\hline IMA 2016-110 & Rubinite & $\mathrm{Ca}_{3} \mathrm{Ti}^{3+}{ }_{2} \mathrm{Si}_{3} \mathrm{O}_{12}$ & Ma et al. (2017b) \\
\hline IMA 2017-078 & Kaitianite & $\mathrm{Ti}^{3+}{ }_{2} \mathrm{Ti}^{4+} \mathrm{O}_{5}$ & Ma (2019); this study \\
\hline
\end{tabular}

\section{MINERAL NAME AND TYPE MATERIAL}

The name kaitianite is derived from the two Chinese words "Kai Tian," meaning creating the heaven/the sky, from the story of "Pan Gu Kai Tian." In ancient Chinese mythology, the giant Pan Gu created the world by separating the heaven and earth from an egg-shaped chaos. The mineral panguite $\left(\left[\mathrm{Ti}^{4+}, \mathrm{Sc}, \mathrm{Al}\right.\right.$, $\mathrm{Mg}, \mathrm{Zr}, \mathrm{Ca}]_{1.8} \mathrm{O}_{3}$; IMA 2010-057, Ma et al. 2012) was named after "Pan Gu" in allusion to the mineral with an ultra-refractory origin being among the first solid materials in the solar system. Type kaitianite formed in the generation following formation of ultra-refractory phases like panguite through oxidation of tistarite, $\mathrm{Ti}_{2} \mathrm{O}_{3}$, and is part of the overarching story of the early solar system.

The Allende meteorite, which fell near Pueblito de Allende, Chihuahua, Mexico, on February 8, 1969, is a CV3 carbonaceous chondrite. The holotype specimen of kaitianite in Allende section UNSM 3510-5 is in the collections of the Smithsonian Institution's National Museum of Natural History, Washington DC, USA. This section also hosts type tistarite (IMA 2008-016).

\section{ANALYTICAL TECHNIQUES}

Electron probe microanalysis (EPMA), highresolution scanning electron microscopy (SEM), energydispersive spectrometer (EDS), and electron backscatter diffraction (EBSD) were used to characterize the composition and structure of the new mineral and associated phases. Backscatter electron (BSE) imaging was performed using a ZEISS 1550VP field emission SEM. EDS analyses were carried out with an Oxford XMax SDD system and the AZtec program on the ZEISS 1550VP SEM. EBSD analyses were performed using an HKL EBSD system on the ZEISS 1550VP SEM, operated at $20 \mathrm{kV}$ and $6 \mathrm{nA}$ in focused beam mode with a $70^{\circ}$ tilted stage and variable pressure mode (25 Pa) using procedures described in $\mathrm{Ma}$ and Rossman (2008). The EBSD system was calibrated using a singlecrystal silicon standard. The structure was determined and cell constants were obtained by matching the experimental EBSD patterns with all known polymorphs of $\mathrm{TiO}_{2}$, Magnéli phases $\left(\mathrm{Ti}_{\mathrm{n}} \mathrm{O}_{2 \mathrm{n}-1}\right), \mathrm{Ti}_{2} \mathrm{O}_{3}$, $\mathrm{Ti}_{3} \mathrm{O}_{5}$, and panguite.

Quantitative WDS elemental microanalyses of the type kaitianite and associated tistarite and rutile were carried out using a JEOL 8200 electron microprobe $(10 \mathrm{kV}$ and $5 \mathrm{nA}$, focused beam) on each phase, as marked in Fig. 1b (corundum grains from the crack were also analyzed, but locations are not indicated in Fig. 1). The focused electron beam is $\sim 120 \mathrm{~nm}$ in diameter. The interaction volume for X-ray generation in kaitianite is $\sim 500 \mathrm{~nm}$ in diameter, estimated using a Casino Monte Carlo simulation of electron trajectory (Drouin et al. 2007). Standards for analysis were anorthite $(\mathrm{Al} K \alpha)$, fayalite $(\mathrm{FeK} \alpha)$, forsterite $(\mathrm{MgK} \alpha)$, $\mathrm{TiO}_{2} \quad(\mathrm{TiK} \alpha)$, and $\mathrm{V}_{2} \mathrm{O}_{5} \quad(\mathrm{VK} \alpha)$. Analyses were processed with the CITZAF correction procedure (Armstrong 1995) and analytical results are given in Table 2. 

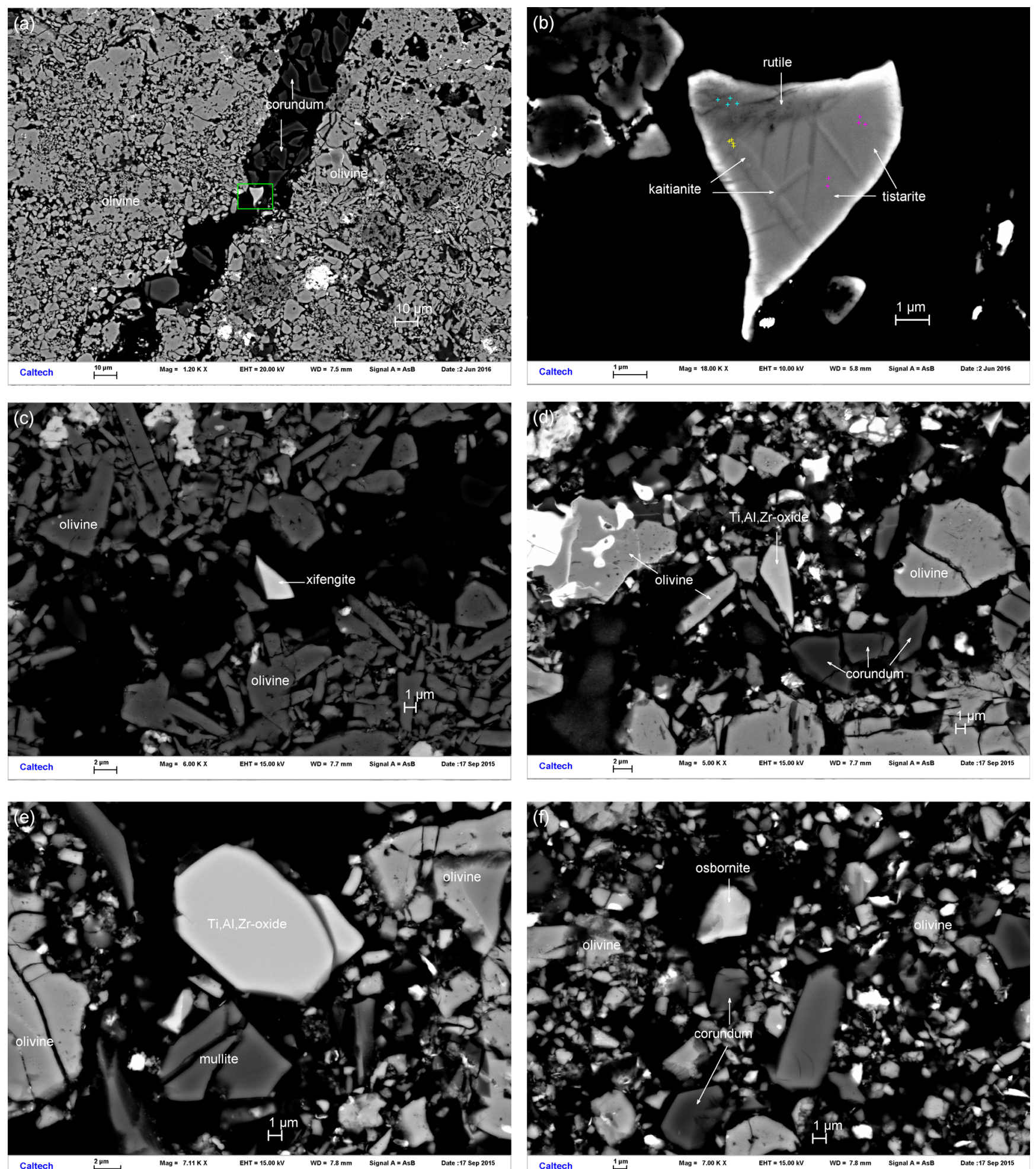

Fig. 1. SEM BSE images showing (a) kaitianite $\left(\mathrm{Ti}^{3+}{ }_{2} \mathrm{Ti}^{4+} \mathrm{O}_{5}\right)$ with tistarite $\left(\mathrm{Ti}_{2} \mathrm{O}_{3}\right)$ and rutile $\left(\mathrm{TiO}_{2}\right)$ in one grain within the rectangle, along with corundum grains in section USNM 3510-5. b) Close-up of kaitianite. The white boundaries of the grain are an edge effect consequence at the high-current, high-contrast setting. Apparent medium gray needles (in BSE) have no EBSD expression (see Fig. 4). EPMA point analyses (cf. Table 2) are marked with crosses on each phase. c) Close-up of xifengite grain. d) The new Ti,Al,Zr-oxide along with corundum. e) One mullite gain and the new Ti,Al,Zr-oxide. f) One osbornite (TiN) grain with corundum. (Color figure can be viewed at wileyonlinelibrary.com.) 
Table 2. EPMA results for type kaitianite, associated tistarite $\left(\mathrm{Ti}_{2} \mathrm{O}_{3}\right)$ and rutile $\left(\mathrm{TiO}_{2}\right)$, and corundum grains in Allende section USNM 3510-5.

\begin{tabular}{|c|c|c|c|c|c|c|c|c|}
\hline Constituent (wt $\%)$ & Kaitianite $(n=4)$ & SD & Tistarite $(n=5)$ & SD & Rutile $(n=4)$ & SD & Corundum $(n=20)$ & SD \\
\hline $\mathrm{Ti}_{2} \mathrm{O}_{3}$ & $56.55^{*}$ & 0.41 & 95.26 & 0.52 & - & & 1.28 & 0.46 \\
\hline $\mathrm{TiO}_{2}$ & $39.29^{*}$ & 0.29 & - & & 97.83 & 0.36 & - & \\
\hline $\mathrm{Al}_{2} \mathrm{O}_{3}$ & 1.18 & 0.11 & 1.03 & 0.06 & 0.3 & 0.06 & 98.63 & 0.87 \\
\hline $\mathrm{MgO}$ & 1.39 & 0.1 & 2.38 & 0.17 & 1.35 & 0.22 & 0.06 & 0.03 \\
\hline $\mathrm{FeO}$ & 0.59 & 0.04 & 0.67 & 0.06 & 0.59 & 0.06 & 0.10 & 0.08 \\
\hline $\mathrm{V}_{2} \mathrm{O}_{3}$ & 0.08 & 0.11 & 0.16 & 0.14 & 0.38 & 0.1 & na & \\
\hline \multirow[t]{2}{*}{ Total } & 99.07 & & 99.5 & & 100.45 & & 100.07 & 0.61 \\
\hline & Molecular formula & & & & & & & \\
\hline \# Oxygen & 5 & & 3 & & 2 & & 3 & \\
\hline $\mathrm{Ti}^{3+}$ & 1.754 & & 1.903 & & - & & 0.018 & \\
\hline $\mathrm{Ti}^{4+}$ & 1.097 & & - & & 0.977 & & - & \\
\hline $\mathrm{Al}$ & 0.052 & & 0.029 & & 0.005 & & 1.980 & \\
\hline $\mathrm{Mg}$ & 0.077 & & 0.085 & & 0.027 & & 0.001 & \\
\hline $\mathrm{Fe}$ & 0.018 & & 0.007 & & 0.007 & & 0.001 & \\
\hline V & 0.002 & & 0.004 & & 0.004 & & - & \\
\hline Sum & 3.000 & & 2.033 & & 1.019 & & 2.001 & \\
\hline
\end{tabular}

$n=$ number of analyses; $\mathrm{SD}=$ one standard deviation of the mean based on all of the analyses; na $=$ not analyzed.

${ }^{*}$ Total titanium, which equals $91.91 \mathrm{wt} \%$ as $\mathrm{Ti}_{2} \mathrm{O}_{3}$, has been partitioned between $\mathrm{Ti}^{3+}$ and $\mathrm{Ti}^{4+}$ in order to make ideal stoichiometry.

\section{RESULTS}

\section{Occurrence and Appearance}

Kaitianite occurs as two crystals, $0.3 \sim 0.6 \mu \mathrm{m} \times$ $3.6 \mu \mathrm{m}$ and $0.2 \mu \mathrm{m} \times 1.1 \mu \mathrm{m}$, in USNM 3510-5 within one irregular grain of tistarite; the kaitianite crystals are in contact with tistarite and rutile (Fig. 1). These Tioxides occur together with grains of $\mathrm{Ti}^{3+}$-bearing corundum, xifengite, mullite, osbornite ( $\mathrm{TiN})$, and a new Ti,Al,Zr-oxide mineral with composition $\left(\mathrm{Ti}^{3+}{ }_{1.16} \mathrm{Al}_{0.57} \mathrm{Zr}_{0.11} \mathrm{Si}_{0.07} \mathrm{Mg}_{0.03}\right)_{\mathbb{2} 1.95} \mathrm{O}_{3}$ (based on three oxygen atoms pfu and assuming all $\mathrm{Ti}$ to be trivalent) in several cracks in Allende matrix (Fig. 1), which consists mainly of olivine with minor troilite and pentlandite. The kaitianite composition is nominally consistent with tistarite, but EBSD shows that the crystal structure is distinct (see the Composition and Crystal Structure section). It is related to the structures of panguite and kangite (Ma et al. 2012, 2013) but is, in contrast, highly ordered. We observed no interaction between minerals within the cracks and minerals along the walls of the crack. It seems that the grains were drawn during sample preparation from the same source as a cluster of refractory phases observed in a chondrule in polished thin section USNM 3510-6. In that object, $\mathrm{Ti}^{3+}$-bearing corundum grains occur with mullite, khamrabaevite ( $\mathrm{TiC}$ ), rutile, an $\mathrm{Fe}-\mathrm{Si}$ alloy, and the type tistarite $\left(\mathrm{Ti}_{2} \mathrm{O}_{3}\right.$; IMA 2008-016) (Fig. 2), as described in
Ma and Rossman (2009a) and Ma et al. (2009). We also discovered an example of the new $\mathrm{Ti}, \mathrm{Al}, \mathrm{Zr}$-oxide mineral in that cluster. USNM 3510-5, which contains the kaitianite, USNM 3510-4, and USNM 3510-6 are adjacent samples from a group of serially sectioned thin sections taken from Allende. The O-isotope analyses of two corundum grains in the cluster in USNM 3510-6 reveal that the grains have compositions well above the terrestrial fractionation line, but they lie on the CCAM line (see fig. 3 of Ma et al. 2009), which is consistent with formation or alteration in an ${ }^{16} \mathrm{O}$-depleted reservoir within our solar system (i.e., these are probably not presolar grains). Those corundum grains are evidently extraterrestrial materials, not from polishing alumina. Such $\mathrm{Ti}^{3+}$-bearing corundum and associated refractory phases identified in sections USNM 3510-5 and USNM 3510-6 were not found in section USNM 3510-4 under careful examination using the same analytical techniques.

\section{Composition and Crystal Structure}

The chemical composition of type kaitianite (Table 2) by low-voltage EPMA (WDS) is (wt \%) $\mathrm{Ti}_{2} \mathrm{O}_{3}$ 56.55, $\mathrm{TiO}_{2} 39.29, \mathrm{Al}_{2} \mathrm{O}_{3} 1.18, \mathrm{MgO} 1.39, \mathrm{FeO} 0.59$, $\mathrm{V}_{2} \mathrm{O}_{3} 0.08$, sum 99.07, showing an empirical formula (based on $5 \mathrm{O}$ atoms pfu) of $\left(\mathrm{Ti}^{3+}{ }_{1.75} \mathrm{Al}_{0.05} \mathrm{Ti}^{4+}{ }_{0.10}\right.$ $\left.\mathrm{Mg}_{0.08} \mathrm{Fe}_{0.02}\right)\left(\mathrm{Ti}^{4+}{ }_{1.00}\right) \mathrm{O}_{5}$, where $\mathrm{Ti}^{3+}$ and $\mathrm{Ti}^{4+}$ are partitioned, assuming a stoichiometry with three cations 


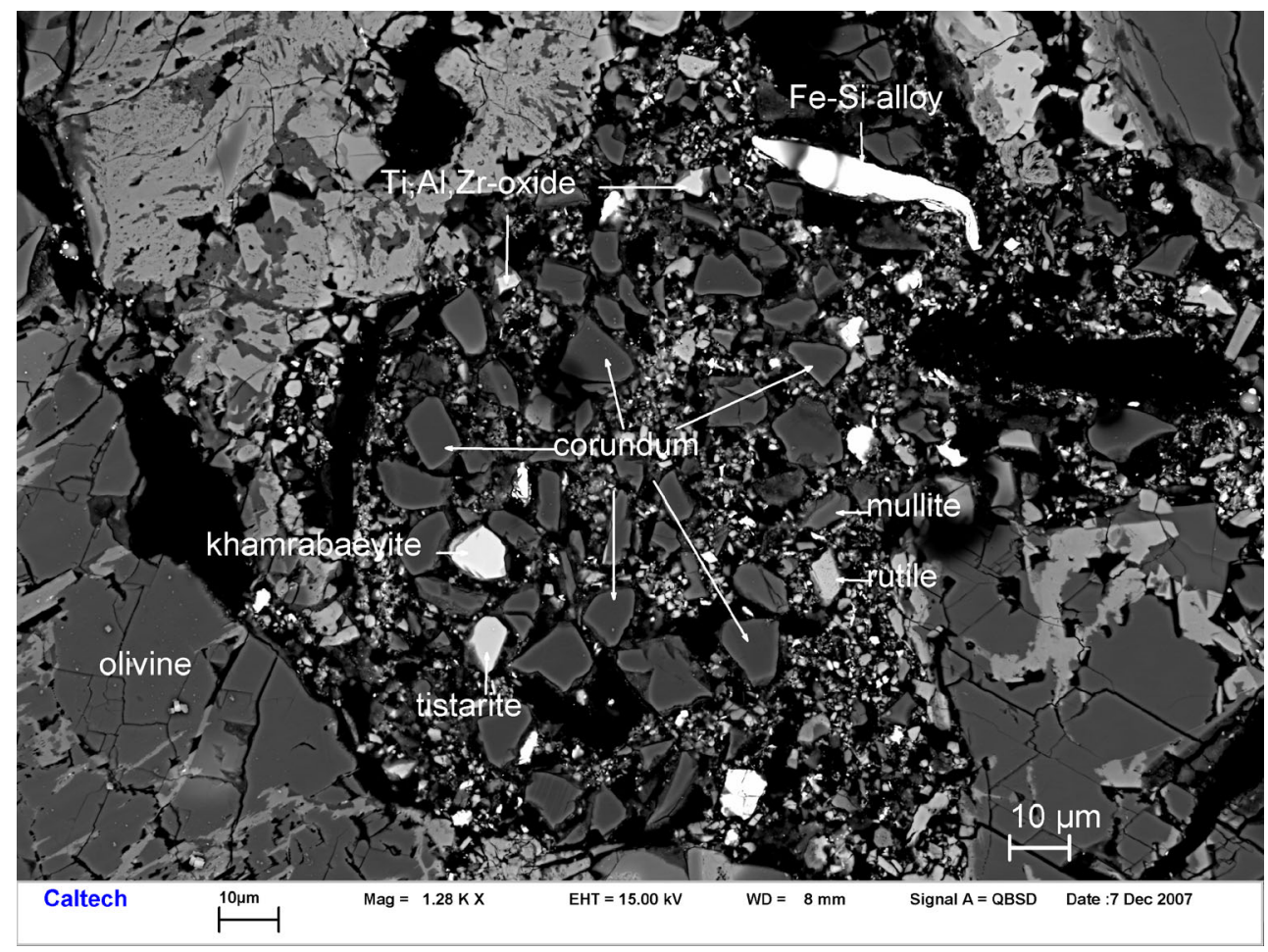

Fig. 2. BSE image showing the cluster of refractory phases corundum, tistarite, rutile, khamrabaevite, mullite, Fe-Si alloy, and the new Ti,Al,Zr-oxide, within a chondrule in USNM 3510-6 (Ma et al. 2009; Ma and Rossman 2009a). (Color figure can be viewed at wileyonlinelibrary.com.)

and five oxygen anions pfu. The endmember formula is $\mathrm{Ti}^{3+}{ }_{2} \mathrm{Ti}^{4+} \mathrm{O}_{5}$, which requires $\mathrm{Ti}_{2} \mathrm{O}_{3}$ 64.28, $\mathrm{TiO}_{2}$ 35.72, total $100.00 \mathrm{wt} \%$. The empirical formula (based on three oxygen atoms pfu) of associated tistarite is $\left(\mathrm{Ti}^{3+}{ }_{1.90} \mathrm{Mg}_{0.08} \mathrm{Al}_{0.03} \mathrm{Fe}_{0.01}\right) \mathrm{O}_{3}$. The empirical formula (based on two oxygen atoms pfu) of associated rutile is $\left(\mathrm{Ti}^{4+}{ }_{0.98} \mathrm{Mg}_{0.03} \mathrm{Fe}_{0.01}\right) \mathrm{O}_{2}$.

The EBSD patterns of kaitianite (Fig. 3) could be indexed only by the $C 2 / c \mathrm{~V}_{3} \mathrm{O}_{5}$-type structure of $\gamma-\mathrm{Ti}_{3} \mathrm{O}_{5}$ (Hong and Åsbrink 1982; Tanaka et al. 2015) with a mean angular deviation of $0.33^{\circ}$. For synthetic $\gamma-\mathrm{Ti}_{3} \mathrm{O}_{5}$, $a=10.115 \AA, \quad b=5.074 \AA, \quad c=7.182 \AA, \quad \beta=112^{\circ}$, $V=341.77 \AA^{3}$, and $Z=4$ (Hong and Asbrink 1982). $\mathrm{X}$-ray powder diffraction data (Table 3 , given in $\AA$ for $\mathrm{CuK \alpha 1}$ and Bragg-Brentano geometry) were calculated using Powder Cell version 2.4 (Kraus and Nolze 1996) for the empirical formula from this study and the atomic coordinates of Tanaka et al. (2015), after transforming from $I 2 / \mathrm{c}$ as used by these authors to $C 2 /$ $c$, the standard setting for Space Group 15. The calculated density is $4.29 \mathrm{~g} . \mathrm{cm}^{-3}$ using the empirical formula and the above cell parameters.

Kaitianite is isostructural with the minerals oxyvanite $\left(\mathrm{V}_{3} \mathrm{O}_{5}\right)$ and berdesinskiite $\left(\mathrm{V}_{2} \mathrm{TiO}_{5}\right)$ (Armbruster et al. 2009), as well as synthetic $\mathrm{Fe}_{2} \mathrm{TiO}_{5}$ and $\mathrm{Cr}_{2} \mathrm{TiO}_{5}$ with a $C 2 / c \mathrm{~V}_{3} \mathrm{O}_{5}$-type structure (Drofenik et al. 1981; Müller-Buschbaum and Bluhm 1988; Pownceby et al. 2001). All of these phases are characterized by two types of octahedral site. One, which contains a $3+$ cation, is highly symmetric (Ti-O

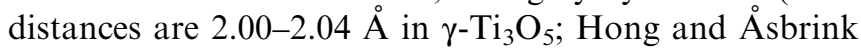
1982). These octahedra share edges and form chains. The second type of cation site forms as pairs of highly distorted face-sharing octahedra (Ti-O distances of $1.88-2.17 \AA$ in $\gamma-\mathrm{Ti}_{3} \mathrm{O}_{5}$; Hong and Asbrink 1982) that are joined to adjacent pairs by shared edges yielding chains that are attached to those of the symmetric octahedra through shared edges.

\section{Associated Minerals}

Tistarite and rutile were identified in the grain with kaitianite by EBSD and EPMA (Table 2; Fig. 1b). BSE imaging and EBSD mapping show that kaitianite occurs between rutile and tistarite (Fig. 4) with the rutile forming an $\sim 1 \mu \mathrm{m}$ layer on one side of the tistarite crystal. Note that there are two- and three-phase contacts, which, as we note below, have important ramifications for origin. There is also nearby corundum (Fig. 1a; Table 2). The corundum grains are not significantly zoned, but there are considerable grain-tograin variations in $\mathrm{Ti}$ (grain averages range from 0.4 to 

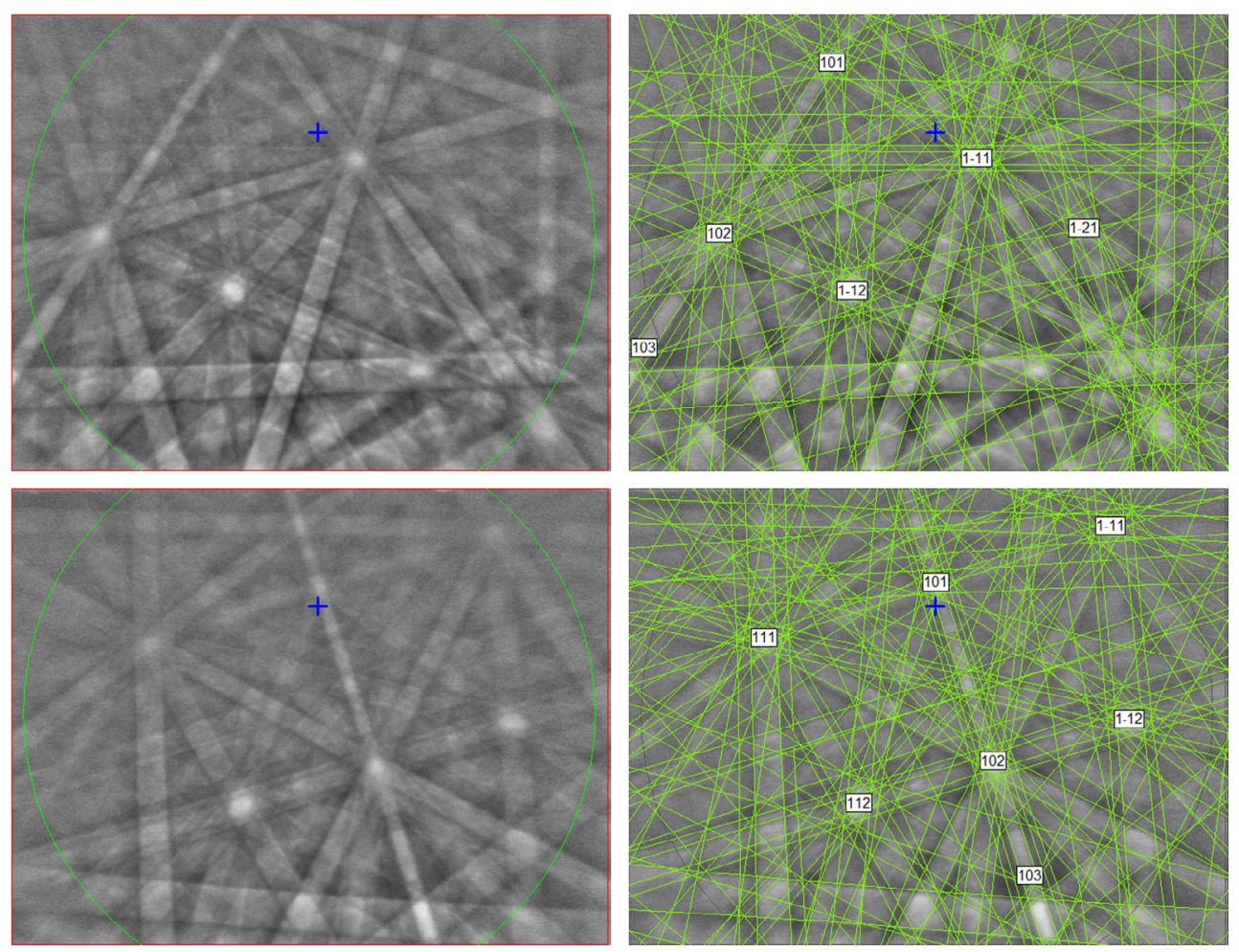

Fig. 3. (Left) EBSD patterns of the larger kaitianite crystal in Fig. 1b, taken at two different orientations, and (right) the patterns indexed with the $C 2 / c \gamma-\mathrm{Ti}_{3} \mathrm{O}_{5}$ structure. (Color figure can be viewed at wileyonlinelibrary.com.)

$2.0 \mathrm{wt} \% \mathrm{Ti}_{2} \mathrm{O}_{3}$; the composition given in Table 2 is the average of analyses from nine different grains). Tibearing xifengite, which was identified by EPMA and EBSD, occurs as one irregular crystal in the crack of the Allende matrix (Fig. 1c) where the kaitianite was found. Its composition by EPMA (wt \%) is $\mathrm{Fe} 69.49, \mathrm{Si}$ 24.83, Ti 3.95, Cr 0.79, V 0.53, total 99.59, showing an empirical formula of $\left(\mathrm{Fe}_{4.45} \mathrm{Ti}_{0.30} \mathrm{Cr}_{0.05} \mathrm{~V}_{0.04}\right) \mathrm{Si}_{3.16}$. EBSD reveals the phase to have a hexagonal $\mathrm{Mn}_{5} \mathrm{Si}_{3}$-type xifengite structure. Xifengite has previously been reported in the lunar anorthosite Dho 280 (Nazarov et al. 2015) and in the Khatyrka CV3 meteorite, which contains a variety of iron silicides and $\mathrm{Al}$ - and $\mathrm{Cu}$-rich alloys (Lin et al. 2017; Ma et al. 2017a). Ti-bearing mullite, identified by EPMA and EBSD, occurs as one broken euhedral crystal (Fig. 1e), showing an empirical formula of $\left(\mathrm{Al}_{5.61} \mathrm{Ti}^{3+}{ }_{0.34} \mathrm{Mg}_{0.05}\right) \mathrm{Si}_{2.01} \mathrm{O}_{13}$. Osbornite (TiN), identified by SEM-EDS and EBSD, occurs as one irregular crystal with corundum grains in a crack of the Allende matrix (Fig. 1f).

We asserted above that the cluster of grains in USNM 3510-6 was likely drawn from the same material as the grains in the crack containing kaitianite shown in Fig. 1. Although this material will be described in a separate publication, we note here that the cluster contains Ti-bearing corundum, mullite, rutile, khamrabaevite (TiC), and tistarite. If we accept the connection to the occurrence of this study, this phase assemblage places additional constraints on the origin of kaitianite. The cluster in section 3510-6 and the crack in USNM 3510-5 (Figs. 1d, 1e, and 2) also contain a new $\mathrm{Ti}^{3+}$-, $\mathrm{Al}-, \mathrm{Zr}$-oxide as irregular-to-euhedral grains with an average empirical formula for the crack occurrence of $\left(\mathrm{Ti}^{3+}{ }_{1.16} \mathrm{Al}_{0.57} \mathrm{Zr}_{0.11} \mathrm{Si}_{0.07} \mathrm{Mg}_{0.03}\right)_{\mathbb{\Sigma} 1.95} \mathrm{O}_{3}$ and a general formula of $\left(\mathrm{Ti}^{3+}, \mathrm{Al}, \mathrm{Zr}, \mathrm{Si}, \mathrm{Mg}\right)_{1.95} \mathrm{O}_{3}$, assuming all $\mathrm{Ti}$ to be $\mathrm{Ti}^{3+}$. Although chemically consistent with tistarite, EBSD (Fig. 5) shows that its crystal structure is distinct. It is related to the structures of panguite and kangite (Ma et al. 2012, 2013) but is, in contrast, highly ordered.

\section{DISCUSSION}

\section{Crystal-Chemical Considerations}

Kaitianite $\left(\mathrm{Ti}^{3+}{ }_{2} \mathrm{Ti}^{4+} \mathrm{O}_{5}\right)$ is the natural form of $\gamma$ $\mathrm{Ti}_{3} \mathrm{O}_{5}$ and the Ti-analog of oxyvanite $\left(\mathrm{V}_{3} \mathrm{O}_{5}\right)$. It is a new member of the berdesinskiite group, which now includes the three minerals berdesinskiite $\left(\mathrm{V}_{2} \mathrm{TiO}_{5}\right)$, oxyvanite, and kaitianite. It joins other Ti-rich minerals from carbonaceous chondrites including perovskite, Al.Ti-diopside, tistarite, rutile, grossmanite, davisite, 
Table 3. Calculated X-ray powder diffraction data for kaitianite $\left(I_{\text {rel }}>1\right)$. The strongest reflections are given in bold.

\begin{tabular}{|c|c|c|c|c|}
\hline & $k$ & $l$ & $d(\AA)$ & $I_{\mathrm{rel}}$ \\
\hline 2 & 0 & 0 & 4.6892 & 53 \\
\hline 1 & 1 & 0 & 4.4627 & 15 \\
\hline-1 & 1 & 1 & 4.0567 & 1 \\
\hline-2 & 0 & 2 & 3.3768 & 75 \\
\hline 0 & 0 & 2 & 3.3295 & 15 \\
\hline-1 & 1 & 2 & 2.9308 & 73 \\
\hline 3 & 1 & 0 & 2.6616 & 100 \\
\hline 0 & 2 & 0 & 2.5370 & 37 \\
\hline-3 & 1 & 2 & 2.5048 & 10 \\
\hline 1 & 1 & 2 & 2.4662 & 59 \\
\hline-4 & 0 & 2 & 2.3827 & 9 \\
\hline 0 & 2 & 1 & 2.3708 & 2 \\
\hline 4 & 0 & 0 & 2.3446 & 6 \\
\hline 2 & 0 & 2 & 2.3334 & 1 \\
\hline-2 & 2 & 1 & 2.2394 & 28 \\
\hline 3 & 1 & 1 & 2.2377 & 21 \\
\hline 2 & 2 & 0 & 2.2314 & 7 \\
\hline-1 & 1 & 3 & 2.1458 & 23 \\
\hline-2 & 2 & 2 & 2.0283 & 29 \\
\hline 0 & 2 & 2 & 2.0179 & 4 \\
\hline-5 & 1 & 1 & 1.8711 & 1 \\
\hline 1 & 1 & 3 & 1.8596 & 1 \\
\hline-5 & 1 & 2 & 1.8464 & 1 \\
\hline-2 & 0 & 4 & 1.7951 & 1 \\
\hline-4 & 2 & 1 & 1.7907 & 2 \\
\hline 5 & 1 & 0 & 1.7593 & 49 \\
\hline-4 & 2 & 2 & 1.7368 & 66 \\
\hline 4 & 2 & 0 & 1.7219 & 6 \\
\hline 2 & 2 & 2 & 1.7174 & 1 \\
\hline-6 & 0 & 2 & 1.6771 & 1 \\
\hline-3 & 1 & 4 & 1.6712 & 67 \\
\hline 0 & 2 & 3 & 1.6705 & 1 \\
\hline 0 & 0 & 4 & 1.6648 & 13 \\
\hline 1 & 3 & 0 & 1.6645 & 1 \\
\hline-1 & 1 & 4 & 1.6597 & 5 \\
\hline 4 & 0 & 2 & 1.6483 & 25 \\
\hline 6 & 0 & 0 & 1.5631 & 4 \\
\hline-1 & 3 & 2 & 1.5301 & 11 \\
\hline-3 & 3 & 1 & 1.5102 & 1 \\
\hline-5 & 1 & 4 & 1.5008 & 3 \\
\hline 3 & 3 & 0 & 1.4876 & 25 \\
\hline 3 & 1 & 3 & 1.4872 & 0 \\
\hline 1 & 1 & 4 & 1.4760 & 3 \\
\hline-2 & 2 & 4 & 1.4654 & 1 \\
\hline-3 & 3 & 2 & 1.4585 & 2 \\
\hline 1 & 3 & 2 & 1.4507 & 52 \\
\hline 2 & 2 & 3 & 1.4498 & 1 \\
\hline-6 & 0 & 4 & 1.4401 & 7 \\
\hline 2 & 0 & 4 & 1.4110 & 19 \\
\hline 0 & 2 & 4 & 1.3919 & 14 \\
\hline-7 & 1 & 2 & 1.3892 & 27 \\
\hline 4 & 2 & 2 & 1.3822 & 19 \\
\hline
\end{tabular}

Table 3. Continued. Calculated X-ray powder diffraction data for kaitianite $\left(I_{\text {rel }}>1\right)$. The strongest reflections are given in bold.

\begin{tabular}{llllr}
\hline & $k$ & $l$ & $d(\AA)$ & $I_{\text {rel }}$ \\
\hline 5 & 1 & 2 & 1.3694 & 1 \\
-7 & 1 & 1 & 1.3678 & 3 \\
-3 & 3 & 3 & 1.3522 & 1 \\
-6 & 2 & 3 & 1.3463 & 2 \\
6 & 2 & 0 & 1.3308 & 3 \\
-5 & 1 & 5 & 1.3053 & 3 \\
-5 & 3 & 2 & 1.2867 & 1 \\
-7 & 1 & 4 & 1.2691 & 2 \\
0 & 4 & 0 & 1.2685 & 4 \\
-8 & 0 & 2 & 1.2640 & 1 \\
5 & 3 & 0 & 1.2561 & 2 \\
-6 & 2 & 4 & 1.2524 & 13 \\
0 & 4 & 1 & 1.2461 & 1 \\
3 & 1 & 4 & 1.2442 & 2 \\
2 & 2 & 4 & 1.2331 & 5 \\
\hline
\end{tabular}

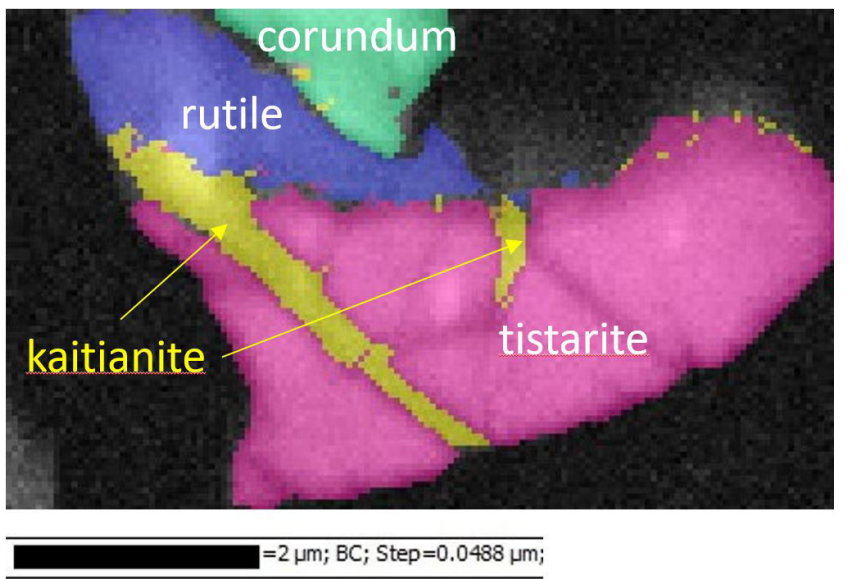

Fig. 4. EBSD phase map revealing the occurrence of kaitianite in contact with tistarite and rutile in the Ti-oxide grain. Kaitianite exhibits a lath shape, as shown in the BSE image (Fig. 1b). The EBSD map is apparently deformed due to the highly tilted surface. Corundum near the top of the panel is a different grain. (Color figure can be viewed at wileyonlinelibra ry.com.)

panguite, kangite, paqueite, zirkelite, tazheranite, rubinite, machiite (Krot et al. 2020), and warkite (Ma et al. 2020). To date, Allende has yielded many $\mathrm{Ti}^{3+}$ rich refractory phases, including grossmanite (Ma and Rossman 2009c), davisite (Ma and Rossman 2009b), rubinite (Ma et al. 2017b), tistarite (Ma and Rossman 2009a), and kaitianite. They formed under extremely 

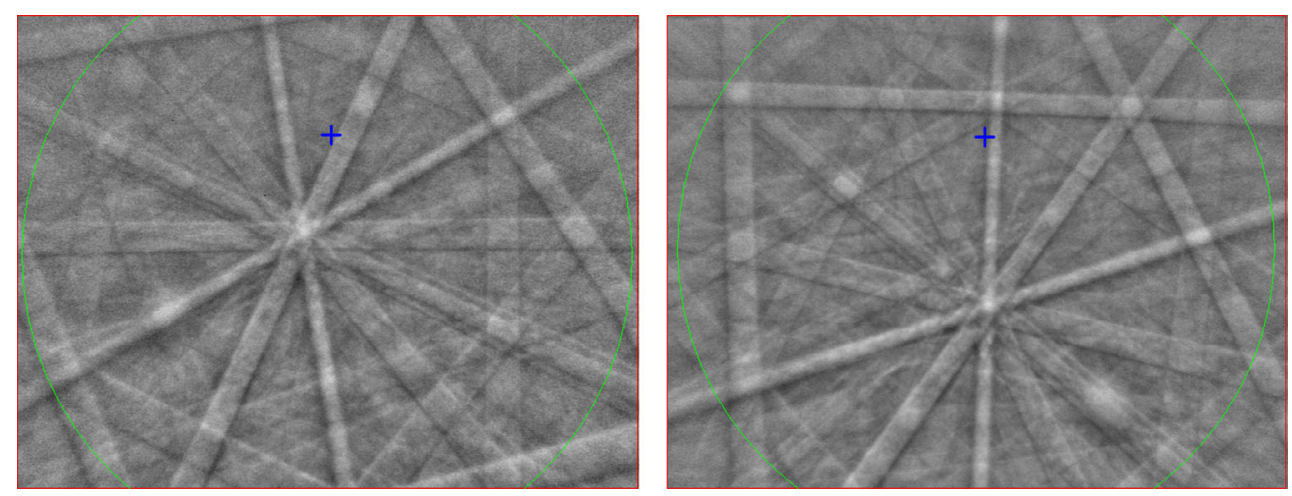

Fig. 5. EBSD patterns of the new Ti,Al,Zr-oxide shown in Figs. 1d and 1e. (Color figure can be viewed at wileyonlinelibrary.c om.)

reduced environments and survived parent body metamorphism.

Kaitianite is a titanium-oxide, but it contains percent level concentrations of $\mathrm{Al}_{2} \mathrm{O}_{3}, \mathrm{MgO}$, and $\mathrm{FeO}$. An apparent partition coefficient $D_{i}^{j-k}$, which refers to the weight ratio of element $i$ between phases $j$ and $k$, can be constructed from data in Table 2 for elements common to pairs of phases in the kaitianite-bearing grain (i.e., rutile, kaitianite, and tistarite). These show that $\mathrm{Al}$ is compatible in kaitianite and tistarite relative to rutile, as might be expected of $\mathrm{Ti}^{3+}$-bearing phases relative to a $\mathrm{Ti}^{4+}$-dominant mineral. All three phases contain significant concentrations of $\mathrm{Mg}$ (1.4-2.4 wt\% $\mathrm{MgO}$ ), but tistarite is substantially more magnesian than either kaitianite or rutile, so much so that, if kaitianite and/or rutile formed by the oxidation of tistarite, then $\mathrm{Mg}$ was either lost to the oxidizing medium or precipitated in nanocrystals - too small for characterization using the SEM.

\section{Formation Mechanisms and Implications for Nebular Environments}

The presence of multiple oxides of $\mathrm{Ti}$ and their contacts in the host grain of kaitianite provides some basic constraints on the formation process. Additional phases in the cracks, including the unnamed $\mathrm{Ti}^{3+}, \mathrm{Al}$, Zr-oxide, xifengite, mullite, osbornite, and corundum, may also be of help in constraining conditions of formation. We first consider possible constraints on temperature for phases we observed in the crack depicted in Fig. 1a and then focus on redox conditions and process. Rutile, which melts at $2130 \mathrm{~K}$ at $1 \mathrm{~atm}$, and tistarite, which melts at $2115 \mathrm{~K}$, are stable over broad ranges in temperature (Chase et al. 1985; Hampl and Schmid-Fetzer 2015). $\beta-\mathrm{Ti}_{3} \mathrm{O}_{5}$, the stable hightemperature form of $\mathrm{Ti}_{3} \mathrm{O}_{5}$, melts incongruently to form $\mathrm{Ti}_{4} \mathrm{O}_{7}$ at $\sim 1940 \mathrm{~K}$ (Hampl and Schmid-Fetzer 2015).
Thus, the mere presence of any of these phases would impose only weak constraints on the temperature of formation. However, the production of kaitianite $(\gamma$ $\left.\mathrm{Ti}_{3} \mathrm{O}_{5}\right)$ likely imposes significant bounds. $\gamma-\mathrm{Ti}_{3} \mathrm{O}_{5}$ is generally regarded as a metastable phase (Åsbrink et al. 1971; Hong 1982). During synthesis at high temperatures, above $\sim 1230 \mathrm{~K}, \beta-\mathrm{Ti}_{3} \mathrm{O}_{5}$ with a pseudobrookite structure is invariably produced. If $\beta-\mathrm{Ti}_{3} \mathrm{O}_{5}$, so produced, is then held at progressively lower temperatures, it apparently remains stable until $\sim 450 \mathrm{~K}$, where it undergoes a reversible transition to $\alpha-\mathrm{Ti}_{3} \mathrm{O}_{5}$. Available thermodynamic data (Chase et al. 1985; Eriksson and Pelton 1993; Waldner and Eriksson 1999; Hampl and Schmid-Fetzer 2015) imply that $\beta-\mathrm{Ti}_{3} \mathrm{O}_{5}$ is actually unstable relative to $\mathrm{Ti}_{2} \mathrm{O}_{3}+\mathrm{Ti}_{4} \mathrm{O}_{7}$ below $\sim 915 \mathrm{~K}$, although this reaction has not, to our knowledge, been observed experimentally. Vapor transport experiments at temperatures in the range of 970-1200 K (e.g., Åsbrink et al. 1971; Hong 1982) often produce $\gamma-\mathrm{Ti}_{3} \mathrm{O}_{5}$ (i.e., kaitianite). This phase is thought to be metastable because extended reaction runs sometimes lead to the transformation of $\gamma-\mathrm{Ti}_{3} \mathrm{O}_{5}$ to $\beta$ $\mathrm{Ti}_{3} \mathrm{O}_{5}$, but the reverse is not observed. Based on the available synthesis data, it is likely that meteoritic kaitianite formed at temperatures below $\sim 1200 \mathrm{~K}$. If the thermodynamic prediction of $\mathrm{Ti}_{2} \mathrm{O}_{3}+\mathrm{Ti}_{4} \mathrm{O}_{7}$ stability relative to $\mathrm{Ti}_{3} \mathrm{O}_{5}$ were to hold in the kinetic environments encountered by kaitianite (i.e., if $\beta-\mathrm{Ti}_{3} \mathrm{O}_{5}$ is unstable relative to $\mathrm{Ti}_{2} \mathrm{O}_{3}+\mathrm{Ti}_{4} \mathrm{O}_{7}$, then $\gamma-\mathrm{Ti}_{3} \mathrm{O}_{5}$ is also unstable relative to $\mathrm{Ti}_{2} \mathrm{O}_{3}+\mathrm{Ti}_{4} \mathrm{O}_{7}$ ), then the formation of kaitianite would also be restricted to temperatures greater than $\sim 915 \mathrm{~K}$. However, it is possible, even likely, that metastable formation of $\gamma$ $\mathrm{Ti}_{3} \mathrm{O}_{5}$ could be kinetically favored over the stable phase assemblage of $\mathrm{Ti}_{2} \mathrm{O}_{3}+\mathrm{Ti}_{4} \mathrm{O}_{7}$ to temperatures below $915 \mathrm{~K}$.

The iron silicide xifengite $\left(\mathrm{Fe}_{5} \mathrm{Si}_{3}\right)$ has a restricted stability field in the Fe-Si system. According to the 
assessment of Cui and Jung (2017), it is only stable between $1090 \mathrm{~K}$, below which it breaks down to the Ferich $\mathrm{B} 2$ alloy and $\mathrm{FeSi}$, and $1360 \mathrm{~K}$, above which it is unstable relative to $\mathrm{Fe}_{2} \mathrm{Si}$ and $\mathrm{FeSi}$. This temperature range $(1090-1360 \mathrm{~K})$ overlaps that expected for the production of kaitianite $(<\sim 1200 \mathrm{~K})$. If we make the gratuitous assumption that both phases formed under roughly the same conditions, then a formation temperature of $1150 \pm \sim 50 \mathrm{~K}$ would account for both phases.

A different type of thermal constraint is implicit in the composition of corundum in USNM 3510-5. Under reducing conditions, up to several mole $\% \mathrm{Ti}$ is soluble in corundum with a solubility limit, which increases with increasing temperature, dictated by the precipitation of $\mathrm{Ti}_{2} \mathrm{O}_{3}$ (Fig. 6; Yasuda et al. 1998). Corundum with a particular concentration of $\mathrm{Ti}_{2} \mathrm{O}_{3}$ can be produced at a temperature higher than this limit (i.e., where the system is undersaturated with respect to tistarite) but not at a lower temperature where tistarite would, at equilibrium, precipitate, thereby lowering the concentration of $\mathrm{Ti}$ in the residual corundum to that of the solubility limit. Since we see no evidence for tistarite in or on corundum grains of USNM3510-5, the line in Fig. 6 marks a limiting equilibrium boundary for tistarite-free corundum. Individual grains shown in Fig. 1 contain $0.27-1.45 \mathrm{~mol} \% \mathrm{Ti}$, a factor of five variation. From Fig. 6, these concentrations translate into minimum temperatures in the range from 1579 $\left(0.27 \mathrm{~mol}_{0} \% \mathrm{Ti}_{2} \mathrm{O}_{3}\right)$ to $1696\left(1.45 \mathrm{~mol}^{\circ} \mathrm{Ti}_{2} \mathrm{O}_{3}\right) \mathrm{K}$. This result suggests that corundum grains in USNM 3510-5 sampled a variety of environments characterized by significant differences in one or more of temperature, the local activity of $\mathrm{Ti}$, and the oxygen fugacity. They cannot have been produced under nearly identical conditions. The complete absence of tistarite in or on corundum suggests that these grains never equilibrated with tistarite, and in particular, never equilibrated with the tistarite grain shown in Fig. 1. Since the required temperatures for the corundum grains are so much higher than likely formation temperatures for kaitianite (>1579-1696 K versus $<1200 \mathrm{~K}$ ), we can also conclude that the corundum did not equilibrate with kaitianite.

At equilibrium, the Ti-O system contains a wide variety of oxides of varying stoichiometry that are sensitive to redox conditions (e.g., Zador and Alcock 1983; Jacob et al. 2000; Gemelli and Camargo 2007). Rutile, the most oxygen-rich of these, is rare but widely distributed in chondritic meteorites (e.g., Buseck and Keil 1966). Rutile can accommodate a modest concentration of oxygen vacancies charge balancing $\mathrm{Ti}^{3+}$ (up to $\sim 0.01$ cations pfu) without perturbing the overall crystal structure. However, further loss of oxygen is accomplished through crystallographic shear

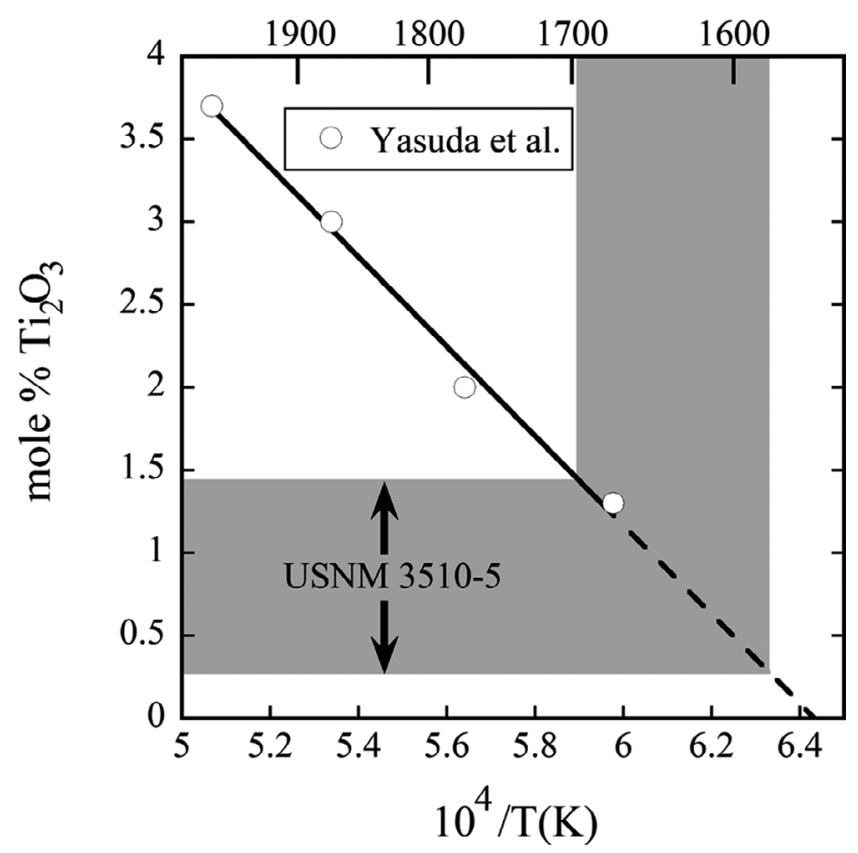

Fig. 6. $10^{4} / \mathrm{T}(\mathrm{K})$ versus $\mathrm{mol} \% \quad \mathrm{Ti}_{2} \mathrm{O}_{3} \quad$ in corundum (temperatures in $\mathrm{K}$ are indicated on the top axis). Data show temperatures and maximum solubilities according to the data of Yasuda et al. (1998). Gray region indicates minimum temperatures required to account for the observed concentrations of $\mathrm{Ti}_{2} \mathrm{O}_{3}$ in corundum from USNM 3510-5.

in which a homologous series of "Magnéli phases" with stoichiometry $\mathrm{Ti}_{\mathrm{n}} \mathrm{O}_{2 \mathrm{n}-1}$, where $n=3$ to $\sim 28$, is produced by the systematic removal of oxygen in planes parallel to the (121) or (132) planes of rutile. This leads to slices $n$ octahedra thick with $\mathrm{Ti}_{2} \mathrm{O}_{3}$ stoichiometry bounded by rutile-like layers. The oxygen defects are eliminated through this mechanism, but the structure is no longer consistent with that of rutile. $\mathrm{Ti}_{3} \mathrm{O}_{5}$ is the most reduced of these structures.

We observe rutile-tistarite, rutile-kaitianite, and kaitianite-tistarite contacts in the grain shown in Figs. $1 \mathrm{~b}$ and 4. No intermediate Magnéli phases are observed. This immediately suggests a nonequilibrium process, as Magnéli phases with $n>3$ have stability fields in temperature-oxygen fugacity space that lie between those of $\mathrm{TiO}_{2}$ and either of $\mathrm{Ti}_{2} \mathrm{O}_{3}$ or $\mathrm{Ti}_{3} \mathrm{O}_{5}$ (e.g., Zador and Alcock 1983; Jacob et al. 2000). We would, for equilibrium, not expect direct contacts between kaitianite or tistarite and rutile. We can, nevertheless, compute redox conditions for the stable equilibrium between kaitianite and tistarite via $3 \mathrm{Ti}_{2} \mathrm{O}_{3}+1 / 2 \mathrm{O}_{2}=2 \mathrm{Ti}_{3} \mathrm{O}_{5}$ and for metastable equilibria involving kaitianite-rutile $\left(\mathrm{Ti}_{3} \mathrm{O}_{5}+1 / 2 \mathrm{O}_{2}=3 \mathrm{TiO}_{2}\right)$ and tistarite-rutile $\left(\mathrm{Ti}_{2} \mathrm{O}_{3}+1 / 2 \mathrm{O}_{2}=2 \mathrm{TiO}_{2}\right)$ using thermodynamic data of Chase et al. (1985). For the first of these three reactions, we have 


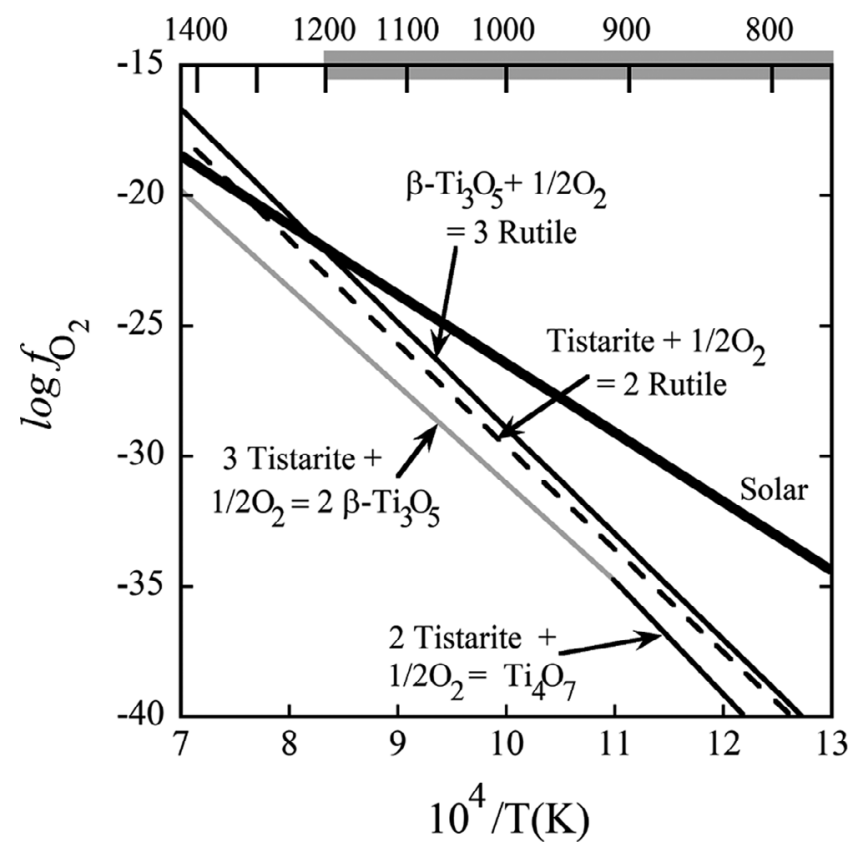

Fig. 7. $10^{4} / \mathrm{T}(\mathrm{K})$ versus $\log f \mathrm{O}_{2}$ for selected metastable and stable equilibria of Ti-oxides. Temperatures in $\mathrm{K}$ are indicated along the top. Values for equilibrium condensation of a cooling gas of solar composition at a total pressure of $10^{-4}$ atm (Ebel 2006) are shown for reference. The gray rectangle along the top axis bounds likely temperatures for the formation of $\gamma-\mathrm{Ti}_{3} \mathrm{O}_{5}$ (i.e., $\leq 1200 \mathrm{~K}$ ).

$$
G_{\rightarrow}=0=2 G_{f, k a i}^{\circ}-3 G_{f, t i s t}^{\circ}-\frac{1}{2} R T \ln f_{\mathrm{O}_{2}},
$$

where $R$ is the gas constant, $T$ the temperature, $f_{O_{2}}$ the oxygen fugacity, $G_{\rightarrow}$ the free energy of reaction, and $G_{f, i}^{\circ}$ the free energy of formation of phase $i$ from the constituent elements. Similar expressions can be written for kaitianite-rutile and tistarite-rutile. These equations were solved for $\log f_{\mathrm{O}_{2}}$ as a function of inverse temperature and the results are shown in Fig. 7, along with the equilibrium for $\mathrm{Ti}_{2} \mathrm{O}_{3}-\mathrm{Ti}_{4} \mathrm{O}_{7}$ (stable relative to $\mathrm{Ti}_{3} \mathrm{O}_{5}$ at temperatures below $915 \mathrm{~K}$, as noted above) and a cooling gas of bulk solar composition at a total pressure of $10^{-4} \mathrm{~atm}$ (Ebel 2006). For temperatures below $\sim 1200 \mathrm{~K}$, as expected for the formation of $\gamma$ $\mathrm{Ti}_{3} \mathrm{O}_{5}$, a grain of tistarite would be susceptible to oxidation, even in a vapor as reducing as gas of solar composition. Of course, more oxidizing redox conditions would also be consistent with oxidation of tistarite. These would include silicate or chondrite dustenriched nebular systems and planetary environments.

As noted above, Magnéli phases have clear stability fields at $\mathrm{Ti} / \mathrm{O}$ ratios between those of $\mathrm{Ti}_{3} \mathrm{O}_{5}$ and $\mathrm{TiO}_{2}$ (e.g., Zador and Alcock 1983; Jacob et al. 2000). Yet, there are no intermediate Magnéli phases in the kaitianite-bearing grain shown in Fig. $1 \mathrm{~b}$ and, in particular, there are none between tistarite and rutile. Experimental reduction of rutile (or anatase) consistently produces intermediate Magnéli phases (Lekanova et al. 2003; Chai et al. 2015). Experimental oxidation of Ti metal produces rutile (anatase at low temperatures) with no intermediate Magnéli phases (Gemelli and Camargo 2007). This suggests that the rutile and kaitianite in USNM 3510-5 are much more likely to be oxidation products of tistarite than is tistarite a reduction product of the more oxygen-rich Tioxides.

Pravdivtseva et al. (2020) reported the evidence of presolar $\mathrm{SiC}$ in an Allende CAI. The presence of $\mathrm{TiC}$ in the cluster of grains from USNM 3510-6 described by Ma et al. (2009) makes it tempting to suggest a presolar origin for the grains there and, by extension, the grains observed in USNM 3510-6. TiC is often observed in presolar graphite and calculated to be present in supernova ejecta and in the stellar winds from AGB stars (e.g., Lattimer et al. 1978; Sharp and Wasserburg 1995; Lodders 2006). However, Ma et al. (2009) showed that oxygen isotopic compositions of corundum grains in USNM 3510-6 were consistent with formation in an ${ }^{16} \mathrm{O}$-depleted reservoir within the solar system and, assuming that the grains USNM 3510-5 and 3510-6 share the same sourcing, this also suggests a solar system origin for grains in USNM 3510-5. Tistarite and Ti-bearing corundum in USNM 3510-5 are nevertheless consistent with formation in an unusually reduced environment. Once formed, these grains were transported to an oxidizing regime where time at temperature was sufficient to partially oxidize tistarite to kaitianite and rutile but insufficient to significantly modify the corundum, which has, thereby, preserved a wide variety of compositions.

\section{CONCLUDING REMARKS}

Allende is a key resource for the exploration of processes and environments in the early solar system and it continues to catalyze new insights through measurement and experiment. New Allende phases can be often used as formational probes to add new voices to the chorus raised by previously studied minerals. For example, kaitianite speaks to an oxidation event promulgated on a tistarite grain that formed under extremely reducing conditions. Coexisting rutile also suggests an oxidation event, but the conditions under which kaitianite can form are substantially more restrictive.

Acknowledgments - SEM, EBSD, and EPMA analyses were carried out at the Caltech GPS Division Analytical 
Facility, which is supported, in part, by NSF Grants EAR-0318518 and DMR-0080065. Tim McCoy and Glenn MacPherson provided basic information on how those USNM sections were prepared at SI-NMNH. We thank Andrew Davis, Steven Simon, and AE Tim Fagan for their critical and constructive reviews.

\section{Editorial Handling-Dr. Timothy Fagan}

\section{REFERENCES}

Armbruster T., Galuskin E. V., Reznitsky L. Z., and Sklyarov E. V. 2009. X-ray structural investigation of the oxyvanite $\left(\mathrm{V}_{3} \mathrm{O}_{5}\right)$-berdesinskiite $\left(\mathrm{V}_{2} \mathrm{TiO}_{5}\right)$ series: $\mathrm{V}^{4+}$ substituting for octahedrally coordinated $\mathrm{Ti}^{4+}$. European Journal of Mineralogy 21:885-891.

Armstrong J. T. 1995. CITZAF: A package of correction programs for the quantitative electron microbeam X-ray analysis of thick polished materials, thin films, and particles. Microbeam Analysis 4:177-200.

Åsbrink G., Åsbrink S., Magnéli A., Okinaka H., Kosuge K., and Kachi S. 1971. A $\mathrm{Ti}_{3} \mathrm{O}_{5}$ modification of $\mathrm{V}_{3} \mathrm{O}_{5}$-type structure. Acta Chemica Scandinavica 25:3889-3890.

Brearley A. J. 1993. Occurrence and possible significance of rare Ti oxides (Magnéli phases) in carbonaceous chondrite matrices. Meteoritics 28:590-595.

Buseck P. R. and Keil K. 1966. Meteoritic rutile. American Mineralogist 51:1506-1515.

Chai G., Huang W., Shi Q., Zheng S., and Wei D. 2015. Preparation and characterization of $\lambda-\mathrm{Ti}_{3} \mathrm{O}_{5}$ by carbothermal reduction. Journal of Alloys and Compounds 621:404-410.

Chase M. W., Davies C. A., Downey J. R., Frurip D. J., McDonald R. A., and Syverud A. N. 1985. JANAF thermonuclear tables, 3rd ed. Washington, D.C.: American Chemical Society.

Cui S. and Jung I.-H. 2017. Critical reassessment of the Fe-Si system. Calphad 56:108-125.

Drofenik M., Golič L., Hanžel D., Kraševec V., Prodan A., Bakker M., and Kolar D. 1981. A new monoclinic phase in the $\mathrm{Fe}_{2} \mathrm{O}_{3}-\mathrm{TiO}_{2}$ system. I. Structure determination and Mössbauer spectroscopy. Journal of Solid State Chemistry 40:47-51.

Drouin D., Couture A. R., Joly D., Tastet X., Aimez V., and Gauvin R. 2007. CASINO V2.42-A fast and easy-to-use modeling tool for scanning electron microscopy and microanalysis users. Scanning 29:92-101.

Ebel D. S. 2006. Condensation of rocky material in astrophysical environments. In Meteorites and the early solar system II, edited by Lauretta D. S. and McSween $\mathrm{H}$. Y. Jr. Tucson, Arizona: University of Arizona Press. pp. 253-277.

Eriksson G. and Pelton A. D. 1993. Critical evaluation and optimization of the thermodynamic properties and phase diagrams of the $\mathrm{MnO}-\mathrm{TiO}_{2}, \mathrm{MgO}-\mathrm{TiO}_{2}, \mathrm{FeO}-\mathrm{TiO}_{2}, \mathrm{Ti}_{2} \mathrm{O}_{3}-$ $\mathrm{TiO}_{2}, \mathrm{Na}_{2} \mathrm{O}-\mathrm{TiO}_{2}$, and $\mathrm{K}_{2} \mathrm{O}-\mathrm{TiO}_{2}$ systems. Metallurgical Transactions $B$ 24:795-805.

Gemelli E. and Camargo N. H. A. 2007. Oxidation kinetics of commercially pure titanium. Revista Matéria 12:525-531.

Hampl M. and Schmid-Fetzer R. 2015. Thermodynamic description of the Ti-O system. International Journal of Materials Research 106:439-453.
Hong S.-H. 1982. Crystal growth of some intermediate titanium oxide phases $\gamma-\mathrm{Ti}_{3} \mathrm{O}_{5}, \beta-\mathrm{Ti}_{3} \mathrm{O}_{5}, \mathrm{Ti}_{4} \mathrm{O}_{7}$ and $\mathrm{Ti}_{2} \mathrm{O}_{3}$ by chemical transport reactions. Acta Chemica Scandinavica A 36:207-217.

Hong S.-H. and Asbrink S. 1982. The structure of $\gamma-\mathrm{Ti}_{3} \mathrm{O}_{5}$ at 297 K. Acta Crystallographica B 38:2570-2576.

Jacob K. T., Hoque S. M., and Waseda Y. 2000. Synergistic use of thermogravimetric and electrochemical techniques for thermodynamic study of $\mathrm{TiO}_{\mathrm{x}}(1.67 \leq \mathrm{x} \leq 2.0)$ at 1573 K. Materials Transactions, JIM 41:681-689.

Kraus W. and Nolze G. 1996. POWDER CELL-A program for the representation and manipulation of crystal structures and calculation of the resulting X-ray powder patterns. Journal of Applied Crystallography 29:301-303.

Krot A. N., Nagashima K., and Rossman G. R. 2020. Machiite, $\mathrm{Al}_{2} \mathrm{Ti}_{3} \mathrm{O}_{9}$, a new oxide mineral from the Murchison carbonaceous chondrite: A new ultra-refractory phase from the solar nebula. American Mineralogist 105:239-243.

Lattimer J. M., Schramm D. N., and Grossman L. 1978. Condensation in supernova ejecta and isotopic anomalies in meteorites. Astrophysical Journal 219:230-249.

Lekanova T. L., Ryabkov Yu I, and Sevbo O. A. 2003. Particle-size effect on the rate of carbon reduction of $\mathrm{TiO}_{2}$. Inorganic Materials 39:715-719.

Lin C., Hollister L. S., MacPherson G. J., Bindi L., Ma C., Andronicos C. L., and Steinhardt P. J. 2017. Evidence of cross-cutting and redox reaction in Khatyrka meteorite reveals metallic-Al minerals formed in outer space. Nature Scientific Reports 7:1637.

Lodders K. 2006. They came from the deep in the supernova: the origin of $\mathrm{TiC}$ and metal subgrains in presolar graphite grains. Astrophysical Journal 647:L37-L40.

$\mathrm{Ma}$ C. 2010. Hibonite-(Fe), (Fe, $\mathrm{Mg}) \mathrm{Al}_{12} \mathrm{O}_{19}$, a new alteration mineral from the Allende meteorite. American Mineralogist 95:188-191.

Ma C. 2018. Kaitianite. IMA 2017-078. CNMNC Newsletter No. 42. Mineralogical Magazine, 82:445-451.

Ma C. 2019. Discovery of kaitianite, $\mathrm{Ti}^{3+}{ }_{2} \mathrm{Ti}^{4+} \mathrm{O}_{5}$, in Allende: A new refractory mineral from the solar nebula. 82nd Annual Meeting of the Meteoritical Society. Abstract no. 6098.

Ma C. and Beckett J. R. 2016a. Burnettite, CaVAlSiO6, and paqueite, $\mathrm{Ca}_{3} \mathrm{TiSi}_{2}\left(\mathrm{Al}_{2} \mathrm{Ti}\right) \mathrm{O}_{14}$, two new minerals from Allende: Clues to the evolution of a V-rich Ca-Al-rich inclusion (abstract \#1595). 47th Lunar and Planetary Science Conference. CD-ROM.

Ma C. and Beckett J. R. 2016b. Majindeite, $\mathrm{Mg}_{2} \mathrm{Mo}_{3} \mathrm{O}_{8}$, a new mineral from the Allende meteorite and a witness to post-crystallization oxidation of a $\mathrm{Ca}-\mathrm{Al}$-rich refractory inclusion. American Mineralogist 101:1161-1170.

Ma C. and Beckett J. R. 2018. Nuwaite $\left(\mathrm{Ni}_{6} \mathrm{GeS}_{2}\right)$ and butianite $\left(\mathrm{Ni}_{6} \mathrm{SnS}_{2}\right)$, two new minerals from the Allende meteorite: Alteration products in the early solar system. American Mineralogist 103:1918-1924.

Ma C. and Krot A. N. 2014. Hutcheonite, $\mathrm{Ca}_{3} \mathrm{Ti}_{2}\left(\mathrm{SiAl}_{2}\right) \mathrm{O}_{12}$, a new garnet mineral from the Allende meteorite: An alteration phase in a Ca-Al-rich inclusion. American Mineralogist 99:667-670.

$\mathrm{Ma}$ C. and Krot A. N. 2018. Adrianite, $\mathrm{Ca}_{12}\left(\mathrm{Al}_{4} \mathrm{Mg}_{3} \mathrm{Si}_{7}\right)$ $\mathrm{O}_{32} \mathrm{Cl}_{6}$, a new Cl-rich silicate mineral from the Allende meteorite: An alteration phase in a Ca-Al-rich inclusion. American Mineralogist 103:1329-1334.

Ma C. and Rossman G. R. 2008. Barioperovskite, $\mathrm{BaTiO}_{3}$, a new mineral from the Benitoite Mine, California. American Mineralogist 93:154-157. 
Ma C. and Rossman G. R. 2009a. Tistarite, $\mathrm{Ti}_{2} \mathrm{O}_{3}$, a new refractory mineral from the Allende meteorite. American Mineralogist 94:841-844.

Ma C. and Rossman G. R. 2009b. Davisite, CaScAlSiO new pyroxene from the Allende meteorite. American Mineralogist 94:845-848.

$\mathrm{Ma}$ C. and Rossman G. R. 2009c. Grossmanite, $\mathrm{CaTi}^{3+} \mathrm{AlSiO}_{6}$, a new pyroxene from the Allende meteorite. American Mineralogist 94:1491-1494.

Ma C., Beckett J. R., Rossman G. R., Connolly H. C. Jr., Guan Y., Eiler J. M., and Hofmann A. E. 2009. In-situ discovery of a cluster of refractory grains in an Allende ferromagnesian chondrule (abstract\# 2138). 40th Lunar and Planetary Science Conference. CD-ROM.

Ma C., Tschauner O., Beckett J. R., Rossman G. R., and Liu W. 2012. Panguite, $\left(\mathrm{Ti}^{4+}, \mathrm{Sc}, \mathrm{Al}, \mathrm{Mg}, \mathrm{Zr}, \mathrm{Ca}\right)_{1.8} \mathrm{O}_{3}$, a new ultra-refractory titania mineral from the Allende meteorite: Synchrotron micro-diffraction and EBSD. American Mineralogist 97:1219-1225.

Ma C., Tschauner O., Beckett J. R., Rossman G. R., and Liu W. 2013. Kangite, (Sc, Ti, $\mathrm{Al}, \mathrm{Zr}, \mathrm{Mg}, \mathrm{Ca}, \square)_{2} \mathrm{O}_{3}$, a new ultrarefractory scandia mineral from the Allende meteorite: Synchrotron micro-Laue diffraction and electron backscatter diffraction. American Mineralogist 98:870-878.

Ma C., Beckett J. R., and Rossman G. R. 2014a. Monipite, MoNiP, a new phosphide mineral in a Ca-Al-rich inclusion from the Allende meteorite. American Mineralogist 99:198-205.

Ma C., Beckett J. R., and Rossman G. R. 2014b. Allendeite $\left(\mathrm{Sc}_{4} \mathrm{Zr}_{3} \mathrm{O}_{12}\right)$ and hexamolybdenum $(\mathrm{Mo}, \mathrm{Ru}, \mathrm{Fe})$, two new minerals from an ultrarefractory inclusion from the Allende meteorite. American Mineralogist 99:654-666.

Ma C., Paque J., and Tschauner O.2016. Discovery of beckettite, $\mathrm{Ca}_{2} \mathrm{~V}_{6} \mathrm{~A}_{16} \mathrm{O}_{20}$, a new alteration mineral in a $\mathrm{V}$ rich Ca-Al-rich inclusion from Allende (abstract \#1704). 47th Lunar and Planetary Science Conference. CD-ROM.

Ma C., Lin C., Bindi L., and Steinhardt P. J. 2017a. Hollisterite $\left(\mathrm{Al}_{3} \mathrm{Fe}\right)$, kryachkoite $(\mathrm{Al}, \mathrm{Cu})_{6}(\mathrm{Fe}, \mathrm{Cu})$, and stolperite $(\mathrm{AlCu})$ : Three new minerals from the Khatyrka CV3 carbonaceous chondrite. American Mineralogist 102:690-693.

Ma C., Yoshizaki T., Krot A.N., Beckett J.R., Nakamura T., Nagashima K., Muto J., Ivanova M.A. 2017b. Discovery of rubinite, $\mathrm{Ca}_{3} \mathrm{Ti}^{3+}{ }_{2} \mathrm{Si}_{3} \mathrm{O}_{12}$, a new garnet mineral in refractory inclusions from carbonaceous chondrites. 80th Annual Meeting of the Meteoritical Society, Abstract no. 6023.
Ma C., Krot A. N., Beckett J. R., Nagashima K., Tschauner O., Rossman G. R., Simon S. B., and Bischoff A. 2020. Warkite, $\mathrm{Ca}_{2} \mathrm{Sc}_{6} \mathrm{Al}_{6} \mathrm{O}_{20}$, a new mineral in carbonaceous chondrites and a key-stone phase in ultrarefractory inclusions from the solar nebula. Geochimica et Cosmochimica Acta 277:52-86.

Müller-Buschbaum H. and Bluhm K. 1988. Weitere magnetische Untersuchungen an $\mathrm{Ti}_{(3-\mathrm{x})} \mathrm{M}_{(\mathrm{x})} \mathrm{O}_{5}$-Phasen $(\mathrm{M}$ $=\mathrm{Al}^{3+}, \mathrm{Fe}^{2+}, \mathrm{Mn}^{2+}, \mathrm{Mg}^{2+}$ ) mit einem Beitrag uber $\mathrm{CrTi}_{2} \mathrm{O}_{5}$. Zeitschrift für allgemeine und anorganische Chemie 558:28-34.

Nazarov M. A., Shornikov S. I., and Demidova S. I. 2015. Origin of native silicon and iron silicides in the Dhofar 280 lunar meteorite. Petrology 23:186-194.

Pownceby M. I., Fisher-White M. J., and Swamy V. 2001. Phase relations in the system $\mathrm{Fe}_{2} \mathrm{O}_{3}-\mathrm{Cr}_{2} \mathrm{O}_{3}-\mathrm{TiO}_{2}$ between 1000 and $1300^{\circ} \mathrm{C}$ and the stability of $(\mathrm{Cr}, \mathrm{Fe})_{2} \mathrm{Ti}_{\mathrm{n}-2} \mathrm{O}_{2 \mathrm{n}-1}$ crystallographic shear structure compounds. Journal of Solid State Chemistry 161:45-56.

Pravdivtseva O., Tissot F. L. H., Dauphas N., and Amari S. 2020. Evidence of presolar $\mathrm{SiC}$ in the Allende Curious Marie calcium-aluminium-rich inclusion. Nature Astronomy 4:617-624.

Sharp C. M. and Wasserburg G. J. 1995. Molecular equilibria and condensation temperatures in carbon-rich gases. Geochimica et Cosmochimica Acta 59:1633-1652.

Tanaka K., Nasu T., Miyamoto Y., Ozaki N., Tanaka S., Nagata T., Hakoe F., Yoshikiyo M., Nakagawa K., Umeta Y., Imoto K., Tokoro H., Namai A., and Ohkoshi S. 2015. Structural phase transition between $\gamma-\mathrm{Ti}_{3} \mathrm{O}_{5}$ and $\delta-\mathrm{Ti}_{3} \mathrm{O}_{5}$ by breaking of a one-dimensionally conducting pathway. Crystal Growth \& Design 15:653-657.

Waldner P. and Eriksson G. 1999. Thermodynamic modelling of the system titanium-oxygen. Calphad 23:189-218.

Yasuda A., Aoki J., and Sakuma T. 1998. Nanoprecipitation in $\mathrm{Al}_{2} \mathrm{O}_{3}-3 \quad \mathrm{~mol} \% \quad \mathrm{Ti}_{2} \mathrm{O}_{3}$ due to oxidation. Ceramics International 24:483-487.

Zador S. and Alcock C. B. 1983. A thermodynamic study of Magneli and point defect phases in the Ti-O system. High Temperature Science 16:187-207.

Zhang A.-C., Ma C., Sakamoto N., Wang R.-C., Hsu W.-B., and Yurimoto H. 2015. Mineralogical anatomy and implications of a Ti-Sc-rich ultrarefractory inclusion from Sayh al Uhaymir $290 \mathrm{CH} 3$ chondrite. Geochimica et Cosmochimica Acta 163:27-39. 